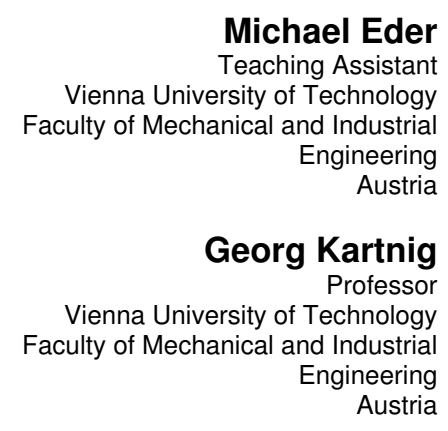

Michael Eder

Austria

\section{Throughput Analysis of S/R Shuttle Systems and Ideal Geometry for High Performance}

Shuttle systems are used in high performance automated storage/retrieval unit load systems. Each storage level is serviced by one transfer car. There is a lift for storage and retrieval on the front side of the load system. A different number of buffer slots are located between the lifts and the respective levels. These systems are already used in various scientific papers and there is also a VDI guideline, but there is only one analytical approach of sufficient accuracy. The problem with all methods for the description of shuttle systems is the geometry of the rack. In automated storage/retrieval unit load systems, the basic geometry of a storage aisle is critical for the throughput. The present study is intended to fill this gap.

Keywords: shuttle-system, storage/retrieval unit load systems, performance, analytical calculation, discrete simulation

\section{INTRODUCTION AND PROBLEM DEFINITION}

During the past years a number of new automated storage and retrieval systems have been introduced to the European logistics market [1] based on individual autonomous vehicles, also called shuttle systems.

A number of research papers have been published in the past to investigate standard configurations [2-9].

In this paper a special configuration of devices, to be described later in more detail, is investigated in its main measure of performance, the throughput and the ideal geometry of the rack for greatest throughput. Analytical equations are presented to calculate throughput as the number of transactions per unit time as a function of rack geometry (length, height) and kinematic data (velocities, accelerations, transfer times) from the beginning until the end of a transaction. The results of the analytical calculations were verified with the simulation package SIMIO. Furthermore, the ideal rack geometry for highest throughput is presented.

The following research questions are dealt with in detail:

- Calculation of throughput depending on rack size

- Ideal rack geometry depending on the storage capacity and storage depth

- Throughput depending on increased storage depth

- Space needed for the rack depending on the storage depth with the same number of storage positions

- Five-axis milling machines

\section{DETAILED DESCRIPTION OF THE SHUTTLE SYSTEM}

The shuttle system discussed here essentially corresponds to the product OSR-Shuttle by courtesy of KNAPP. It

Received: February 2016, Accepted: March 2016

Correspondence to: Michael Eder,

Teaching Assistant, Vienna University of Technology,

Faculty of Mechanical and Industrial Engineering

E-mail: g.kartnig@tuwien.ac.at

doi:10.5937/fmet1602174E

(C) Faculty of Mechanical Engineering, Belgrade. All rights reserved features a shuttle at each rack level and one lift for storage and one for retrieval. A different number of buffer slots are arranged between lift and shuttle. During the storage cycle, the lift transfers the container to the buffer. Subsequently, the container is picked up from the buffer (temporarily decoupled) by the shuttle and stored on the rack. The retrieval process takes place the same way in the reverse direction. The shuttles can also implement multi-depth storage. This means, if a container which is not in the first position on the rack has to be retrieved, the containers in front must be restored.

\subsection{System description}

The shuttle system consists of four devices:

\section{Rack}

The rack contains the storage locations for the unit loads and horizontal guidance rails for the shuttle. Average rack dimensions have lengths varying between 10 and 150 meters and heights between 2 and 30 meters. Storage locations can be single to five-fold deep.

\section{Shuttles}

The shuttles contain transfer devices operating orthogonally to the main guidance rails. After the load is transferred to the shuttle, it travels along the horizontal $\mathrm{x}$ axis from the I/O point to the required storage location. In the case of retrieval the operation takes place in reverse. Only one shuttle travels on each tier [5].

\section{Lift}

Vertical transportation along the z-axis is enabled by two separate lifts, one for the input and one for the output operation. The input lift moves the load from the $\mathrm{I} / \mathrm{O}$ point at $\mathrm{z}=0$ to the input buffer at the required tier. The output lift operates in the reverse direction [5].

\section{Buffers}

Each tier has a different number of input buffer slots and output buffer slots arranged opposite each other. 
When a load is retrieved, the shuttle transfers it from the vehicle platform to the buffer slot, from where it will be retrieved by the output lift at a later point in time. The buffer therefore enables a decoupling of shuttle and lift operations. As the shuttle has no waiting time at the output lift, it can be used for a different function and improve performance.

Figure 3 shows the geometric arrangement and the system layout of the shuttle system with buffer locations at the end of the main aisle.

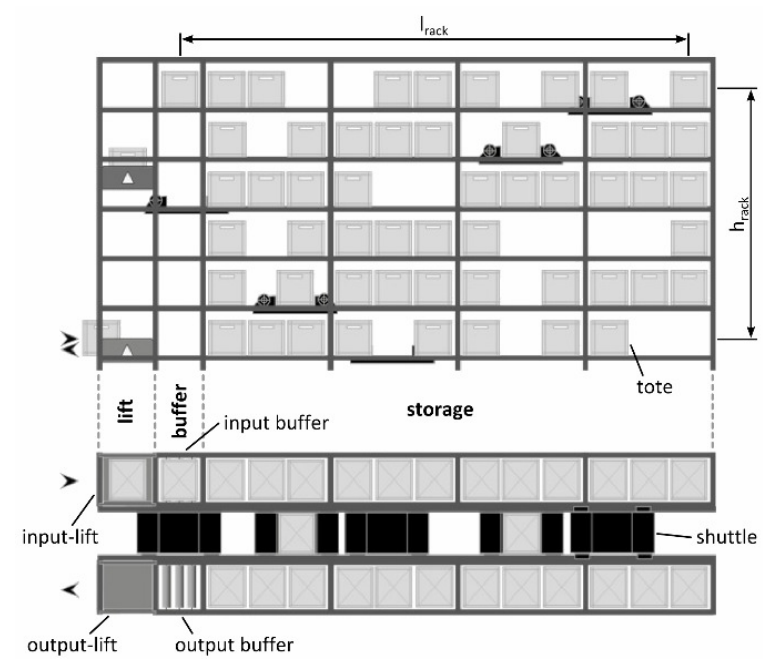

Figure 1. Shuttle system [5]

\subsection{Functional description}

\section{Input process}

The input process describes the movement of loads from the I/O point to the storage position in the rack. A load to be stored waits in the queue at the I/O point until a vertical motion of the lift transports the load to the target level and transfers it to the input buffer position. Here it will wait until it can be transferred to the shuttle, which transports the load horizontally and transfers it to the final storage position (Figure 2).

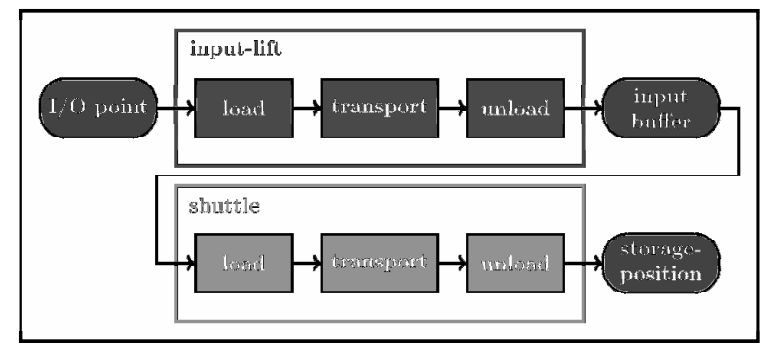

Figure 2. Input process

\section{Output process}

The output process describes the movement of loads from the retrieval location to the $\mathrm{I} / \mathrm{O}$ position at the front of the rack. A load to be retrieved waits in the order queue at the retrieval location until a horizontal motion of the shuttle transports the load to the output buffer position. If the storage rack has multiple depths, it may be that the first load is not the correct one. Then this load must be restored and the process resumes. After a possible waiting time to empty the buffer, a transfer mechanism moves the load to the output buffer position.
Here it will wait until it can be transferred to the vertical lift, which transports it to the final I/O point (Figure 5).

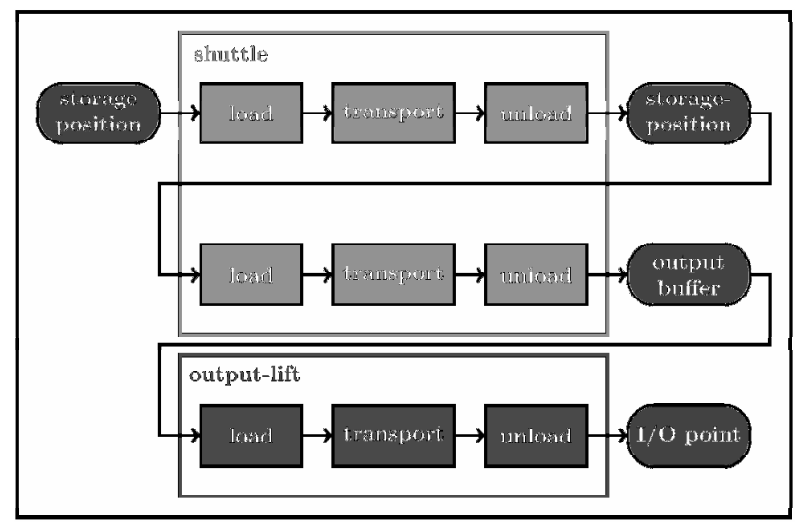

Figure 4. Output process

The control rules operate the lifts with single commands and the shuttles with dual commands. This means, that after transporting a load to the storage position, a shuttle travels empty to the next retrieval position, and from there it transports the retrieved load to the output buffer, from where it is then removed by the lift.

\section{ANALYTICAL CALCULATION OF THROUPUT}

The following calculation refers to input operation. The output operation takes place in the reverse direction but is otherwise the same, so that the results are also valid for this. For this reason the throughput of the entire system can be calculated.

The following investigation refers to only one storage level of the described shuttle system. Such a level can be considered as open M|M|1|K-model of the queuing theory.

The feature of this queuing model is that the arrival and operating process have the so-called Markov property. The property, which is also called "loss of memory", which means that all influences of the past are displayed in the current state of a process and only influence the further course of the process with this condition. The current state of the queuing system and the probability of transition to another state must be known for the mathematical description of the model.

Because only one shuttle operates at each level, there is only one operator station. That is the reason for the "1" in the designation.

The " $K$ " in the designation means that this queuing system has a limited capacity $=\mathrm{K}$. That is, the number of units in the waiting system (= queue + operator station) is limited to the value $\mathrm{K}$. In the present case $\mathrm{K}$ is 2, equivalent to the number of buffer places + the number of units in the operating station (= shuttle) relative to a level. For such a model, the following equation for calculating the throughput can be found in [6].

$$
\vartheta=\frac{1}{t_{a}} \cdot \frac{1-\rho^{K}}{1-\rho^{K+1}}
$$

The utilization rate $\rho$ is the quotient of arrival rate $\lambda$ and the service rate $\mu$ or as the ratio of operating time $t_{0}$ and inter-arrival time $t_{\mathrm{a}}$ : 


$$
\rho=\frac{\lambda}{\mu}=\frac{t_{o}}{t_{a}}
$$

The operating time $t_{0}$ (= expected cycle time value of a shuttle during double cycle) is produced from simple kinematic considerations and based on equal distribution of the expected storage positions in the rack levels[7]:

$$
\begin{aligned}
& t_{o}=t_{\text {shuttle }}=\frac{4}{3} \frac{l_{\text {rack }}}{v_{\text {shuttle }}}+3 \frac{v_{\text {shuttle }}}{a_{\text {shuttle }}} \\
& +t_{\text {load/unload_shuttle }} \\
& +w_{\text {restore }} \cdot t_{\text {restore }}
\end{aligned}
$$

The above equation includes the travel time, the acceleration times, loading and unloading as well as the time required for restoring.

The inter-arrival time $t_{a}$ is produced from the expected value of the cycle time of the storage lift $t_{\text {lift }}$. This is calculated analogously to the cycle time of the shuttles - but for a single match - to[7]:

$$
t_{\text {lift }}=\frac{h_{\text {rack }}}{v_{\text {lift }}}+2 \frac{v_{\text {lift }}}{a_{\text {lift }}}+t_{\text {load/unload_lift }}
$$

This equation includes the travel time again, the acceleration times and loading and unloading of the lift.

To get $t_{a}, t_{\text {lift }}$ must be multiplied by the number of storage levels of the shuttle system, because the input lift has to serve $n$ levels and therefore the individual level is served on average every n-th lift cycle:

$$
t_{a}=t_{\text {lift }} \cdot n
$$

Thus $\rho$ can be calculated and in turn $\vartheta$. However, this $\vartheta$ only represents the throughput of one single rack level, the throughput of the entire shuttle system is simply produced by multiplying by the number of levels:

$$
\vartheta_{\text {system }}=\vartheta \cdot n
$$

The calculation approach remains valid regardless of rack dimensions as well as lift- and shuttle speeds. This means, that this queuing model remains valid for workloads $\rho>1$.

Based on these data (Table 1) the throughput results are shown in Figure 4 for racks with $50 \mathrm{~m}, 75 \mathrm{~m}$ and $100 \mathrm{~m}$ in length with single depth storage.

Table 1. System parameters

\begin{tabular}{|c|c|c|}
\hline & lift & shuttle \\
\hline velocity & $5 \mathrm{~m} / \mathrm{s}$ & $2 \mathrm{~m} / \mathrm{s}$ \\
\hline acceleration & $7 \mathrm{~m} / \mathrm{s}^{2}$ & $2 \mathrm{~m} / \mathrm{s}^{2}$ \\
\hline load-/unload time & $2.8 \mathrm{~s}$ & $4.0-16.8 \mathrm{~s}$ \\
\hline vertical pitch & \multicolumn{2}{|c|}{$\mathrm{p}_{\mathrm{v}}=0.4 \mathrm{~m}$} \\
\hline horizontal pitch & \multicolumn{2}{|c|}{$\mathrm{p}_{\mathrm{h}}=0.5 \mathrm{~m}$} \\
\hline
\end{tabular}

You can see, that the difference in throughput between the different lengths is only at lower racks. At higher racks the length of the rack does not influence the throughput as much.

Furthermore, as an example the following graph shown in Figure 5 for multi-depth storage describes the $100 \mathrm{~m}$ multi-depth rack storage.
In this graph you can see that the influence of the storage depth is greater at the left side. This is based on the fact that, at lower racks the throughput is more dependent on the shuttle performance. As you can see, the storage depth is irrelevant on higher racks.

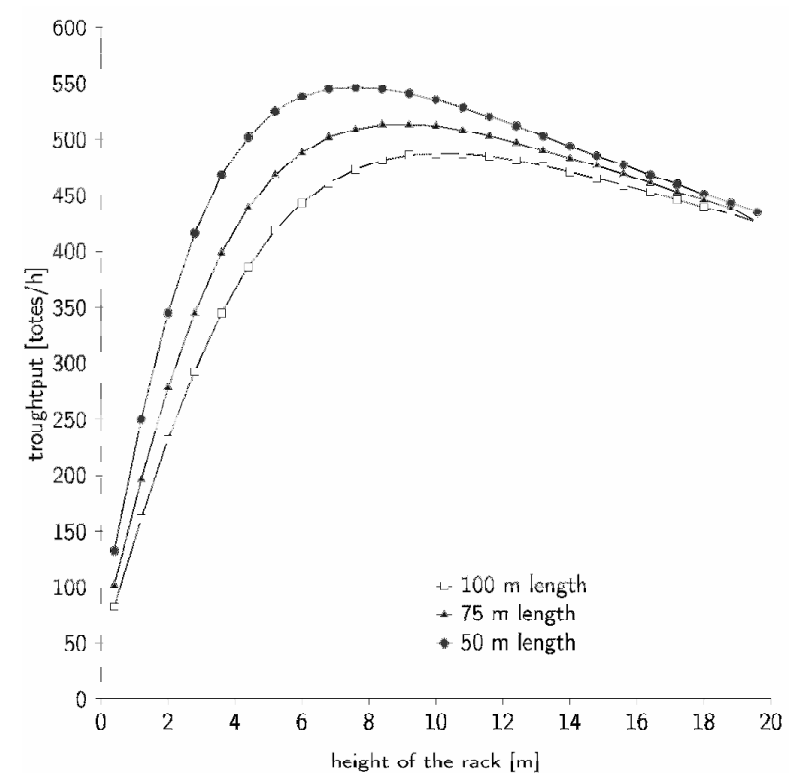

Figure 4. Throughput $\vartheta_{\text {system }}$ of a shuttle system with single depth rack

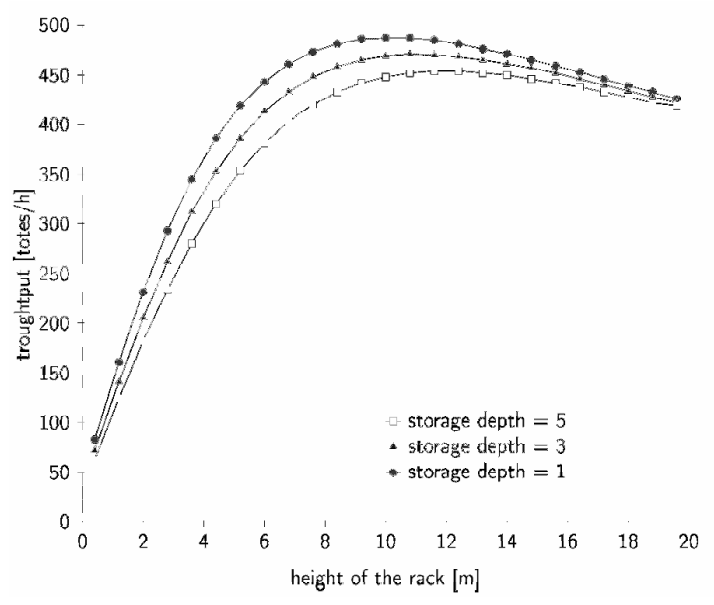

Figure 5. Throughput $\vartheta_{\text {system }}$ of a shuttle system with multidepth rack at $100 \mathrm{~m}$ rack length

\section{DISCRETE SIMULATION OF A SHUTTLE SYSTEM}

In order to validate the results of the analytical calculation, the shuttle system described was also examined by means of discrete simulation. Figure 6 shows a screenshot of the SIMIO model. The storage locations are gray, the input buffer slots are green, the output buffer slots are represented in light blue. Shuttles, lifts and containers are represented by corresponding symbols. The rack has a horizontal pitch of $0.5 \mathrm{~m}$ and a vertical pitch of $0.4 \mathrm{~m}$.

The simulation starts with an empty rack, which is filled in single cycle mode to a filling level of $90 \%$ in single depth storage and filling levels of $10 \%, 50 \%$, and $90 \%$ for multi-depth storage. It is then switched to the double cycle mode: This determines by means of a random generator, which containers are to be removed and into which storage slot the container is to be placed. 


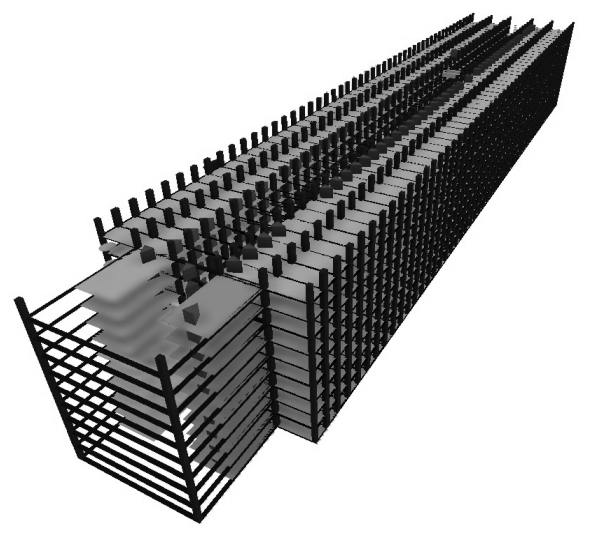

Figure 6. SIMIO model of a shuttle system

In SIMIO a certain number of containers (e.g. 2000 units) that are handled is specified. The evaluation of the results is carried out after a running-in period, which is $10 \%$ of the number of handled containers. These simulation runs are repeated 30 times to obtain a statistically reliable result.

Consequently, Fig. 7 shows the determined throughput of the shuttle system compared with the analytically calculated throughput. We can see that there is good concordance between calculation and simulation. In the worst case the difference is $8 \%$, which is a planning instrument of a tolerable magnitude. The difference is due to alternating between single cycle and double cycle of the shuttle to obtain an optimal throughput.

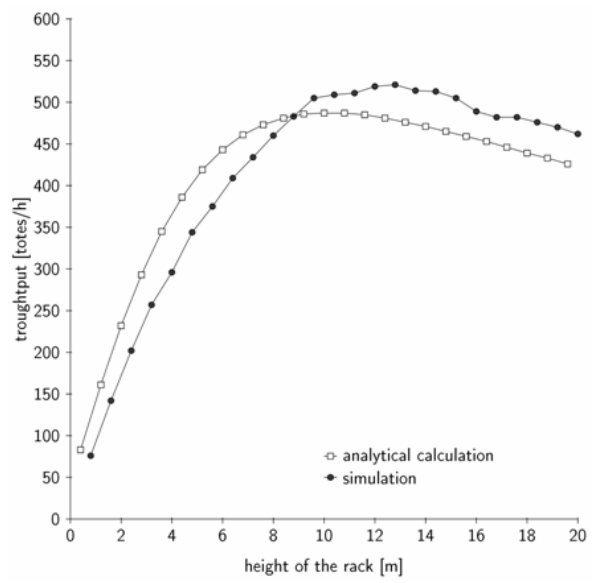

Figure 7. Throughputs of a shuttle system with a rack length of $100 \mathrm{~m}$ achieved by analytical calculation and by simulation

\section{IDEAL GEOMETRY OF THE RACK FOR GREATEST THROUGHPUT}

A rack geometry providing maximum throughput for a given number of storage slots is the goal of every engineer. In order to achieve this geometry a linear optimization of the analytical calculation must be carried out.

$$
\frac{\partial \vartheta_{\text {system }}}{\partial l_{\text {rack }}}=0
$$

This equation produces the optimal length for a given height. From this result the optimal length to height ratio can be calculated for the respective configurations.

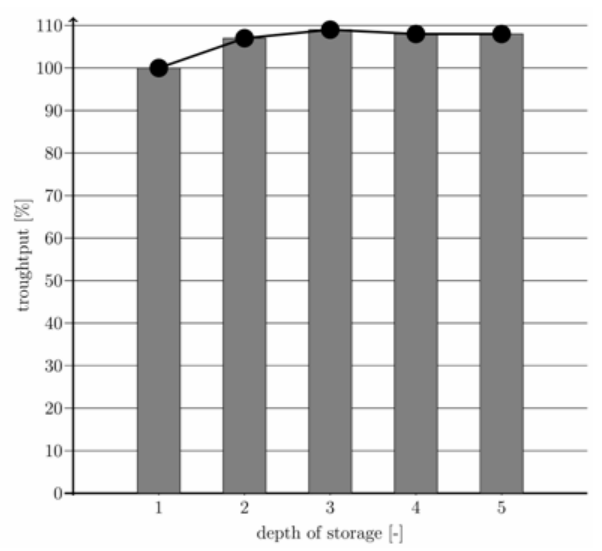

Figure 8. Throughputs of a shuttle system with optimized geometry and multi-depth storage

Figure 8 shows the difference in throughput on the storage depth. It is very interesting to note, that the throughput increases the higher the storage depth until triple-depth storage and then remains constant.

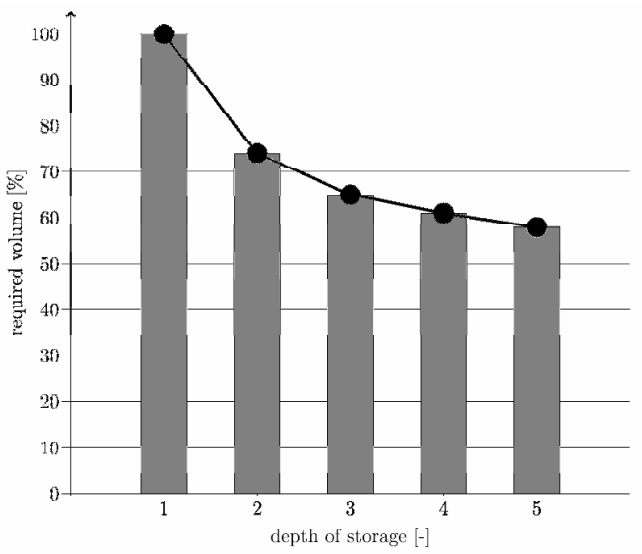

Figure 9. Space required for a shuttle system with the same number of storage slots and multi-depth

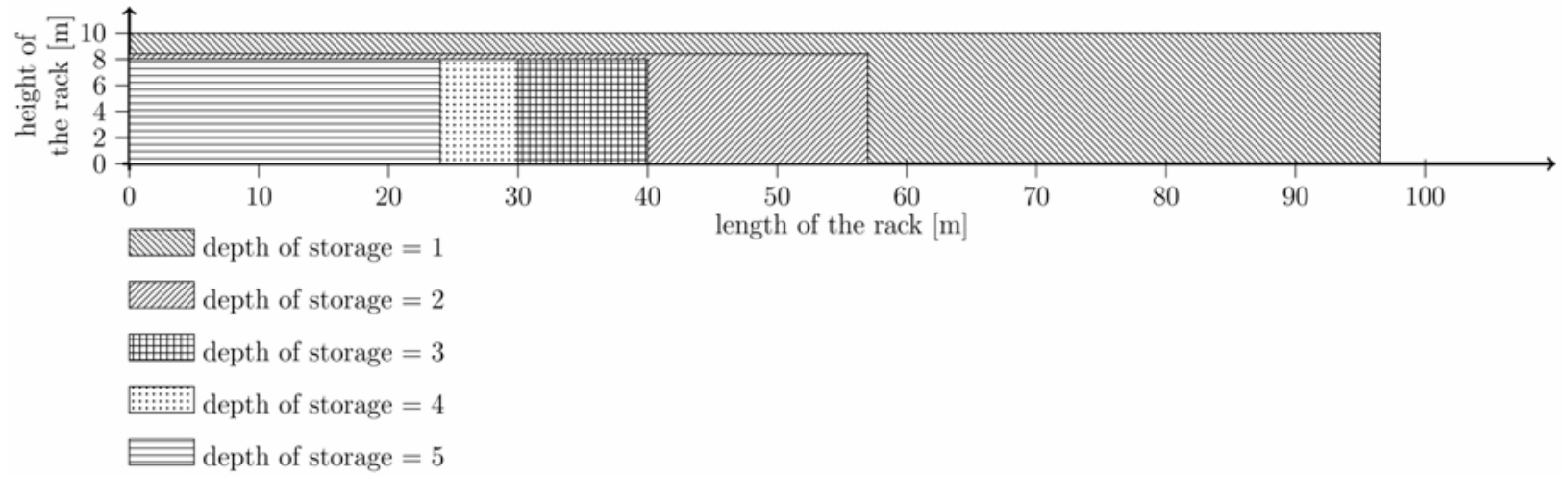

Figure 10. Dimensions of the optimized rack 

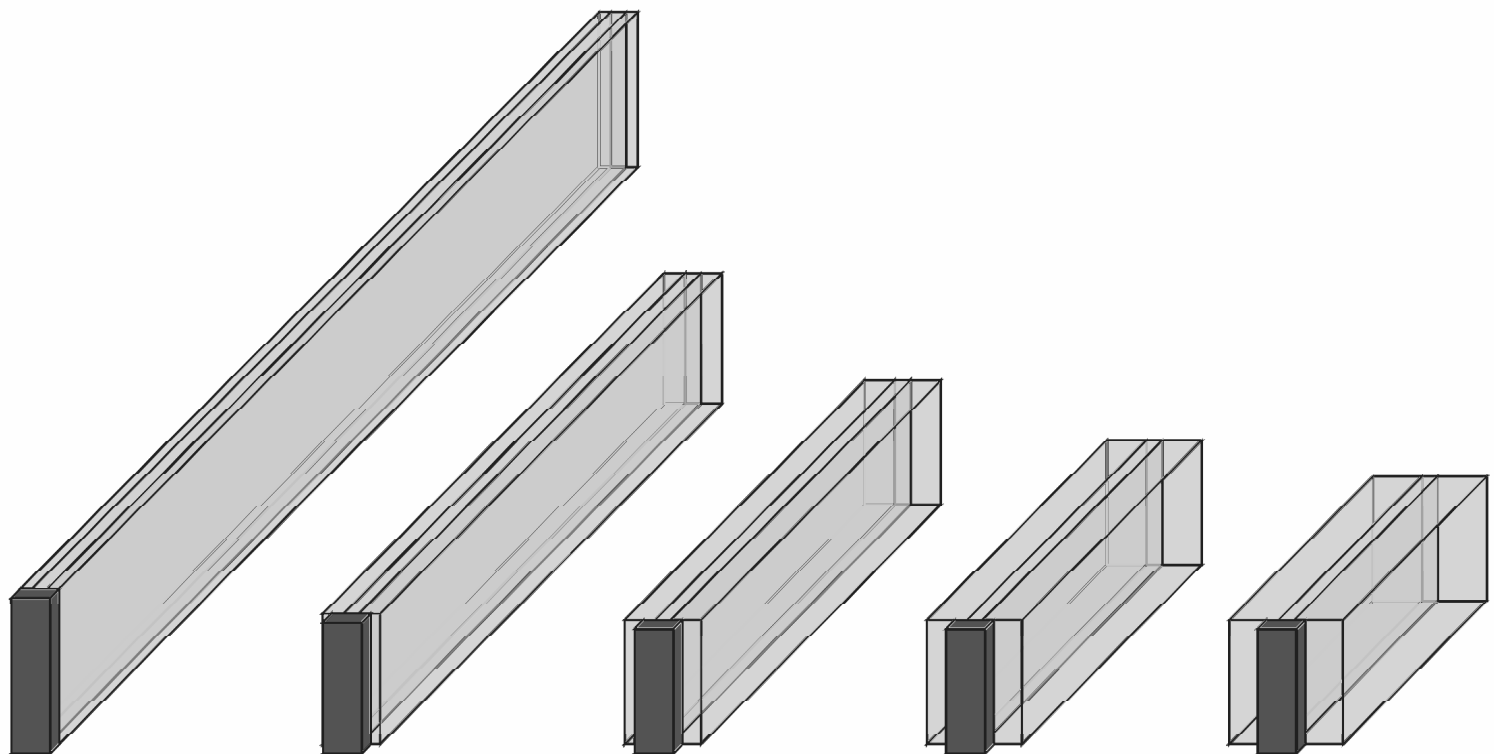

depth of storage $=1$ depth of storage $=2$ depth of storage $=3$ depth of storage $=4$ depth of storage $=5$

$$
t p=100 \% \frac{\text { totes }}{h} \quad t p=107 \% \frac{\text { totes }}{h} \quad t p=109 \% \frac{\text { totes }}{h} \quad t p=108 \% \frac{\text { totes }}{h} \quad t p=108 \% \frac{\text { totes }}{h}
$$

Figure 11. Dimensions of the optimized rack with different throughput dependent on the depth of storage

In triple depth storage the increase in throughput is 109 percent in comparison to single-depth storage.

Figure 10 shows the dimensions of the optimized rack geometries. A fundamental observation from this figure, is that the length decreases as the storage depth increases. However the height only decreases to triple depth storage and eventually remains constant.

Figure 11 shows the racks with their dimensions in 3D. From this figure, the proportions of the individual racks can be compared with each other. Lifts and buffer slots for the storage and retrieval are always marked dark gray. The aisle where the shuttle operates is marked light gray, the rack walls with different storage depths are marked in gray. In this figure, the same knowledge exists as in the previous figure, the length becomes shorter as the storage depth increases, the height decreases, but only to triple-depth storage. In addition you can see here, that the width increases with the depth of storage.

The space required is an indicator of the cost of the building around the storage system. In general the less volume is required, the lower the costs.

Figure 9 shows the space required for the storage function of the storage depth. Single-depth storage is indicated by 100 percent. With double-depth storage it is only 74 percent. This space requirement drops to 58 percent for five-fold depth of storage.

\section{CONCLUSION}

In this paper an analytical approach was introduced for the throughput calculation of shuttle systems. This approach was verified through comparison with a corresponding simulation model. Moreover, with this analytical approach it is possible to determine the optimum rack geometry for shuttle systems, whether they are single-depth or multi-depth. Further research will be extended to shuttles that can handle more storage levels.

\section{REFERENCES}

[1] Heptner, K.: Shuttles unter der Lupe, DHF, 5/2011

[2] Roy, S.: Design and Analysis of Unit-load Warehouse Operations using Autonimous Vehicles, $\mathrm{PhD}$ Dissertation, 2011

[3] Heragu, S. S., Cai, X., Krishnamurty, A., Malmborg, C. J.: An online conceptualization tool for $A V S / R S$ and $A S / R S$, Progress in Material Handling Research, 2008

[4] Krishnamurty, A., Heragu, S. S., Malmborg, C. J.: Blocking effects on performance of warehouse systems with autonomous vehicles, Progress in Material Handling Research, 2010

[5] Karnig, G., Oser, J.: Throughput Analysis of S/R shuttle systems, Progress in Material Handling Research, 2014

[6] Baum, D.: Grundlagen der Warteschlangentheorie, Springer-Verlag, 2013

[7] Eder, M.: Analytische Berechnung der Umschlagleistung von Shuttle-Systemen und Verifikation dieser mittels Simulation, Master thesis, TU Wien, 2014

[8] Kartnig, G., Eder, M.: Spielzeitberechnung von Shuttle-Systemen, VDI-Berichte 2234, 2015

[9] VDI 2692.: Shuttle-Systeme für Kleinbehälterlagerung, 2013

\section{NOMENCLATURE}

$\begin{array}{ll}t_{a} & \begin{array}{l}\text { inter-arrival time } \\ \text { operating time }\end{array} \\ t_{o} & \begin{array}{l}\text { expected value of the cycle time of } \\ \text { the shuttle } \\ \text { expected value of the cycle time of } \\ t_{\text {lift }}\end{array} \\ h_{\text {rack }} & \begin{array}{l}\text { the lift } \\ \text { height of the rack }\end{array}\end{array}$




\begin{tabular}{|c|c|}
\hline$l_{\text {rack }}$ & length of the rack \\
\hline$v_{\text {lift }}$ & velocity of the lift \\
\hline$v_{\text {shuttle }}$ & velocity of the shuttle \\
\hline$a_{\text {lift }}$ & acceleration of the lift \\
\hline$a_{\text {shuttle }}$ & acceleration of the shuttle \\
\hline$t_{\text {load/unload_lift }}$ & loading/unloading time of the lifts \\
\hline$t_{\text {load/unload_shuttle }}$ & $\begin{array}{l}\text { loading/unloading time of the } \\
\text { shuttles }\end{array}$ \\
\hline$w_{\text {restore }}$ & probability for restoring a container \\
\hline$t_{\text {restore }}$ & $\begin{array}{l}\text { expected time for restoring a } \\
\text { container }\end{array}$ \\
\hline$n$ & number of storage levels \\
\hline$K$ & capacity of the queuing system \\
\hline
\end{tabular}

\section{Greek symbols}

$\vartheta$
$\vartheta_{\text {system }}$
$\rho$
$\lambda$
$\mu$

throughput of a storage level throughput of the whole shuttle system utilization rate arrival rate service rate

\section{АНАЛИЗА КАПАЦИТЕТА СКЛАДИШНИХ ШАТЛ СИСТЕМА И ИДЕАЛНА ГЕОМЕТРИЈА ЗА ДОСТИЗАҢЕ ВИСОКИХ ПЕРФОРМАНСИ}

\section{М. Едер, Г. Картниг}

Шатл системи се примењују код аутоматизованих складишних система високих перформанси за јединичне терете. Сваки ниво складишта се опслужује једним транспортним возилом. Постоји лифт за складиштење на предњој страни складишног система. Између лифтова и одговарајућих нивоа постоји различит број међупростора. Овакви системи су већ били коришћени у различитим научним радовима, а постоје и VDI препоруке, али само за аналитички приступ са задовољавајућом тачношћу. Проблем који се јавља код свих метода за описивање шатл система је геометрија регала. Код аутоматизованих складишних система за јединичне терете основна геометрија ходника складишта је критична са аспекта капацитета. Изложена студија треба да допринесе решавању поменутог проблема. 